\title{
AN OBJECTIVE ASSESSMENT OF MEN'S PHYSICAL ACTIIITY DURING COOPER TEST BASED ON THE DIRECT MONITORING BY ACCELEROMETER ACTIGRAPHWGT3X
}

\author{
Jarosław Herbert, $A, D, E$ Piotr Matłosz, ${ }^{A, B, C}$ Wojciech Czarny, ${ }^{D, E}$ Maciej Śliż \\ Faculty of Physical Education, University of Rzeszów, Poland

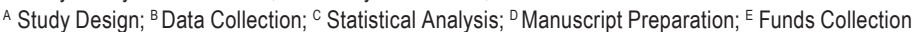 \\ Address for coprespondence: \\ Address for correspondence: \\ Jarosław Herbert \\ University of Rzeszów \\ Faculty of Physical Education \\ Towarnickiego Street 3c, 35-959 Rzeszów, Poland \\ E-mail: herbertjarek@onet.eu
}

\begin{abstract}
Ahstract. Physical activity should play an important role at every age and on every stage of human life. It affects health, well-being and the quality of life. The authors of the paper have shown the use of accelerometer as a device for testing physical activity. They used a group of runners, who during a promoting project of physical activity called "Cooper Test for all", applied accelerometer ActiGraph WGT3X. It was placed on the person's waist. The use of accelerometer valuably complements the survey methods aimed at physical activity levels.
\end{abstract}

KeV Worlls: physical activity, accelerometer ActiGraph WGT3X, cooper test

\section{Introduction}

Physical activity (PA) accompanies us our whole lives, to a smaller or larger extent and in different areas, while being "an integral component of a comprehensive process of adaptation in the history of human evolution" (Malina 1988). Furthermore, PA blends in individual lifestyle, acting as its priority and a connecting component, essential in health promotion (Drabik 1996). As the results of clinical and epidemiological studies on health population show numerous diseases are more prevalent or develop much more in the group of people who use little physical activity or do not take it at all, than in those who regularly perform moderate or vigorous physical activity (Vuori 2004).

One of the most effective methods of developing overall strength in physical education and recreation is the continuous method (cross-country, cross-country skiing and ice skating, rowing, longer marches and field walking or running, cycling). This method is used especially in its monotonous variant, but also in the diversified variant. 
Forms of cyclic movement structure prevail. The most effective means for shaping children's and young people's fitness is running, but in case of adults and elderly people those are only marches.

Running, especially in the fresh air, is, from the physiological point of view, the most comprehensive form of exercise, because it can involve almost the whole body, all its systems, especially - which is important for the prevention of cardiovascular disease - it increases the effort of the heart and circulatory system, as well as it improves ventilation of lungs, contributing to the improvement of metabolic mechanisms (metabolism) and supply body in oxygen. Systematically practiced cross-country courses also have a beneficial effect on strengthening muscles and skeletal system (Bielski 1996). Nowadays, a continuous 12-minute run (Cooper test), a run over a distance of one mile, a long endurance run used in Eurofit test are considered as relevant strength tests in population research (Osiński 2001). Cooper test is the most popular and recommended by many scientists. According to current trends, all tests should be focused on diagnosis of regularities of the basic course of functional processes and should be useful in the creation of healthy behaviors. Control should also facilitate the design of further work and thus, become a pretext teach how to shape your body, improve health. Generally speaking - how to live in physical culture.

The method of data collecting through questionnaires is simple but very subjective; it often gives inaccurate results. Respondents have usually trouble with defining exact walk distance and this is often the only physical activity which people perform every day. The final conclusions of all research questionnaires should be drawn very carefully. Objectification of the level of undertaken physical activity can happen in this case thanks to small-sized mobile devices operating on the basis of accelerometry (e.g. ActiGraph). The device mentioned above, worn by respondents, for example, on their waist, is stimulated proportionally to the movement of the entire body and it allows the measurement of physical activity during several-day periods, as well as in minutes or even seconds (Dwyer et. al. 2007). Accelerometers have become the most accurate, available and widely used devices to monitor physical activity (Esliger and Tremblay 2007; Troiano and Freedson 2010). Accelerometers are widely accepted as important devices for an objective measurement of physical activity and ActiGraph is the most commonly used brand (Kelli et al. 2013). Several studies have documented validity and reliability of activity accelerometers and their ability to track physical activity (Bassett et. al. 2000; Silcott et et al. 2011).

\section{Aim of the study}

The main purpose of the article was to analyze physical activity in a group of men during Cooper test. The aim of the study was to analyze, compare and contrast parameters, such as: BMI (body mass index), Mets (metabolic equivalent of work), kcals (energy balance), number of steps.

\section{Material and Method}

The study was conducted during a promotional project of physical activity called "Cooper Test for All" on the professional athletics track with tartan surface, in the stadium located at the University of Rzeszów, Faculty of Physical Education. All participants proceeded to trial in the morning. The study involved six randomly selected men who were participants in the project mentioned above. The number of respondents was dictated by the fact that authors had only one accelerometer. The necessary condition for participation in the test was the age between 20 and 50 on the day of the event. The respondents were at the following ages: 29, 39, 41, 42, 42 and 49 years old. The average weight of the group was $80.8 \mathrm{~kg}$ and it ranged between 71 and $98 \mathrm{~kg}$. The average body height was $175.1 \mathrm{~cm}$, the tallest man was $180 \mathrm{~cm}$ tall and the two shortest men $-170 \mathrm{~cm}$ tall each. 
Table 1. Data of participants with their running distance

\begin{tabular}{|c|c|c|c|c|c|c|}
\hline Number & 1 & 2 & 3 & 4 & 5 & 6 \\
\hline Age & 29 & 39 & 41 & 42 & 42 & 49 \\
\hline Body height $[\mathrm{cm}]$ & 180 & 170 & 178 & 170 & 175 & 178 \\
\hline Weight [kg] & 89 & 71 & 98 & 71 & 74 & 82 \\
\hline BMI & 24.16 & 25.88 & 24.57 & 27.47 & 30.93 & 24.57 \\
\hline Profession & Electrician & Medical lifeguard & Soldier & Teacher & Computer specialist & Company Chairman \\
\hline Covered distance $[\mathrm{m}]$ & 2,625 & 3,190 & 2,140 & 2,680 & 2,950 & 2,645 \\
\hline
\end{tabular}

Source: the authors' research.

To assess the level of resistance, the authors applied 12-minutes KH Cooper test (continuous run). In many physiological studies significant correlation between the effect of 12 minutes run and body aerobic endurance was identified. The test was conducted according to the instructions of Drabik (1989). This trial had already been popularized in the educational school system and it is quite easy to conduct. The distance can be covered not only by running, but also marching in this test. Within 12 minutes one has to cover the longest possible distance. Therefore, also motivation constitutes a very important question.

Table 2. Criteria of Cooper test $(20-50+$ years old $)$

\begin{tabular}{|c|c|c|c|c|c|c|}
\hline \multirow{2}{*}{ Age } & \multirow{2}{*}{ Sex } & \multicolumn{5}{|c|}{ Criteria } \\
\hline & & very good & good & average & bad & very bad \\
\hline \multirow{2}{*}{ 20-29 years old } & M & $2,800+m$ & $2,400-2,800 \mathrm{~m}$ & $2,200-2,399 \mathrm{~m}$ & $1,600-2,199 \mathrm{~m}$ & $1,600-m$ \\
\hline & W & $2,700+m$ & $2,200-2,700 \mathrm{~m}$ & $1,800-2,199 \mathrm{~m}$ & $1,500-1,799 \mathrm{~m}$ & $1,500-m$ \\
\hline \multirow{2}{*}{ 30-39 years old } & M & $2,700+m$ & $2,300-2,700 \mathrm{~m}$ & $1,900-2,299 \mathrm{~m}$ & $1,500-1,899 \mathrm{~m}$ & $1,500-m$ \\
\hline & W & $2,500+m$ & $2,000-2,500 \mathrm{~m}$ & $1,700-1,999 \mathrm{~m}$ & $1,400-1,699 \mathrm{~m}$ & $1,400-m$ \\
\hline \multirow{2}{*}{$40-49$ years old } & $M$ & $2,500+m$ & $2,100-2,500 \mathrm{~m}$ & $1,700-2,099 \mathrm{~m}$ & $1,400-1,699 \mathrm{~m}$ & $1,400-m$ \\
\hline & W & $2,300+m$ & $1,900-2,300 \mathrm{~m}$ & $1,500-1,899 \mathrm{~m}$ & $1,200-1,499 \mathrm{~m}$ & $1,200-m$ \\
\hline \multirow{2}{*}{$50+$ years old } & $M$ & $2,400+m$ & $2,000-2,400 \mathrm{~m}$ & $1,600-1,999 \mathrm{~m}$ & $1,300-1,599 \mathrm{~m}$ & $1,300-m$ \\
\hline & W & $2,200+m$ & $1,700-2,200 \mathrm{~m}$ & $1,400-1,699 \mathrm{~m}$ & $1,100-1,399 \mathrm{~m}$ & $1,100-m$ \\
\hline
\end{tabular}

Source: Cain et al. (2013).

According to the interpretation of the results in the Cooper test (Table 2), four persons from the group of participants achieved very good results according to their age group, while two others recorded good results in the body efficiency test proposed by Cooper (1970).

Body mass index (BMI) for each participant was also calculated on the base of data obtained in the study. According to the interpretation, three respondents had normal weight $(\mathrm{BMI}=24)$, and three others were overweight $(\mathrm{BMI}=25-30)$. The respondents did both sedentary work (computer specialist, teacher, electrician, president of the company) and work requiring high physical activity (soldier, paramedic).

Accelerometer ActiGraphWGT3X was placed on the person's waist to evaluate selected parameters of physical activity in the group of respondents. Accelerometer measured acceleration in three planes and also all obtained data were calculated into one value called the vector value being the square root of the square sum of activity measurements for each vector. This tool also calculated the number of steps taken by the subjects during Cooper test (Hussey et. al. 2007; Midorikawa et. al. 2007). 


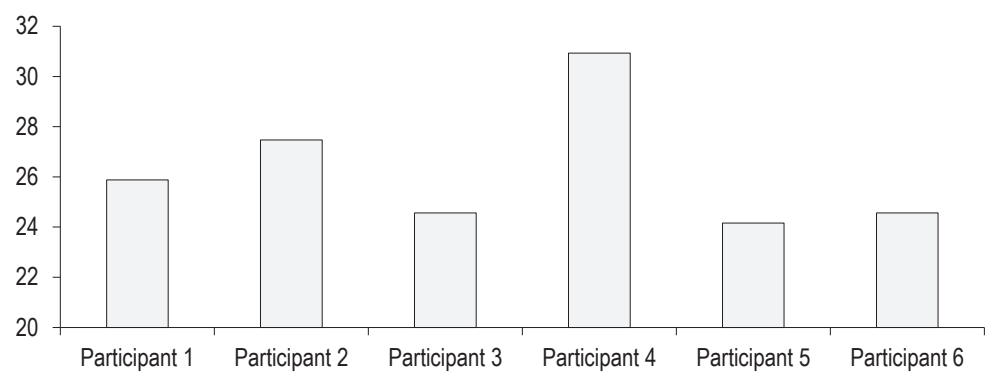

Figure 1. Body mass index BMl of men

Source: the authors' research.

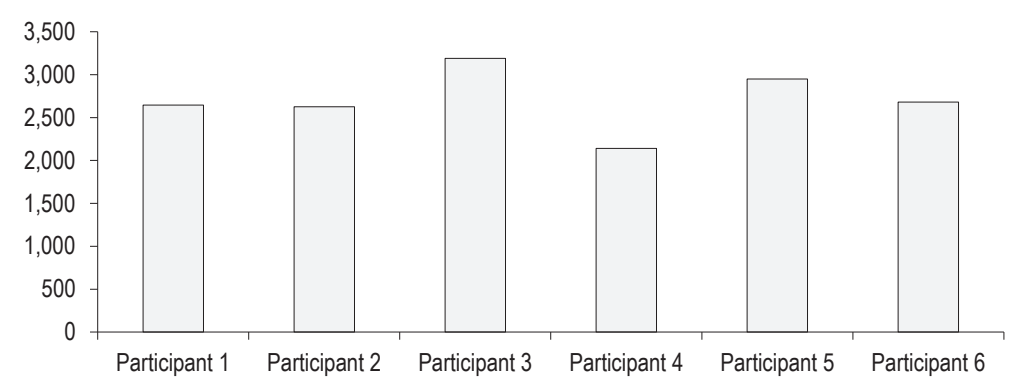

Figure 2. Distance covered during Cooper test [m]

Source: the authors' research.

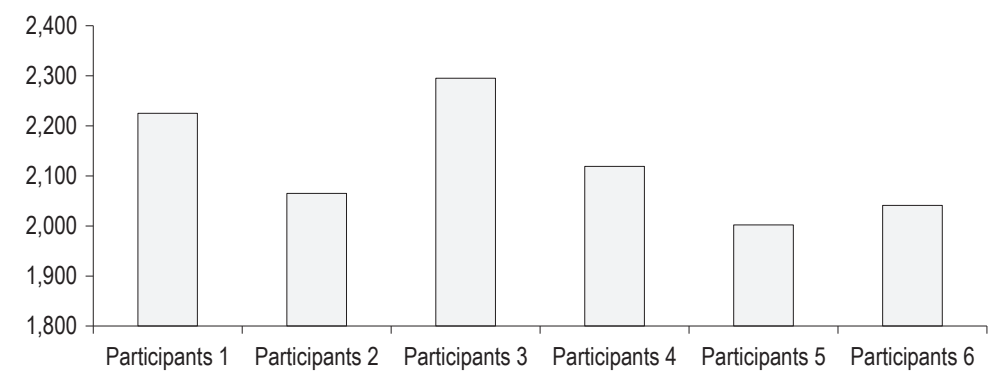

Figule 3. Number of steps made by respondents during Cooper test

Source: the authors' research. 


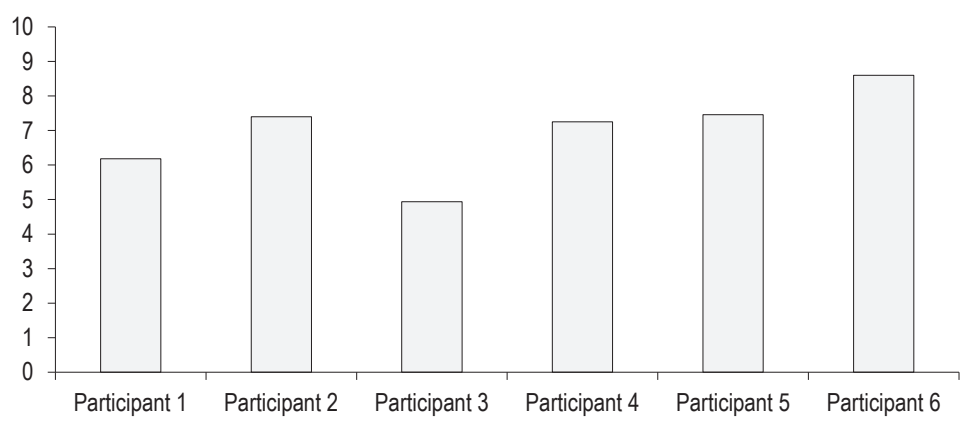

Figure 4. METs values of the energy balance of respondents

Source: the authors' research.

The use of accelerometer allowed the researchers to determine movement from a quantitative and qualitative perspective by recording changes in the acceleration of body and their subsequent conversion to energy expenditure expressed in kcal, as well as to calculate the energy balance in the individual respondents expressed in MET (Herbert and Czarny 2013; Osiński 2003).

\section{Methods of statistical analysis}

Statistic StatSoft 10 Programme was used by authors for statistical analysis. Nonparametric tests were used for comparison of selected quantitative traits. The choice was dictated by the small size of the study group and the fact that the condition of normal distribution of all studied variables was not met. Compliance of those distributions with normal distribution was verified with the use of Shapiro - Wilk test. The correlation was obtained from the Spearman's rank correlation test and determined factors of correlation are significant with $<0.05$. The result of this test can range between -1 and 1 , while extreme values indicate a very strong correlation between variable $A$ and variable $B$. However, when the result is equal or close to 0 it indicates that there is no direct relationship between these variables. A positive test value meant that where the value of one variable is increased the value of the other variable adopts higher values as well and vice versa, when the value of one variable is decreased also other values decreased. Negative Pearson $r$ factor indicated that with the increase in the value of one variable the value of the other variable decreased and vice versa, if one value decreased the value of the other variable increased. The result of this test can range between -1 and 1 and extreme values are ideal to show a complete correlation between variable $A$ and variable $B$. The result equal or close to 0 indicates no relationship between these variables. The authors adopted the following interpretation of the results of the Spearman's rank correlation in the paper:

- 0.9-1.0 - very strong correlation,

- 0.7-0.9- strong correlation,

- 0.4-0.7 - average correlation,

- 0.1-0.4 - weak correlation,

- below 0.1 - no or very weak correlation.

Data of parameters generated by accelerometer were exported to Excel spreadsheet whereby authors have illustrated it with the use of graphs. 


\section{Results and Discussion}

Accelerometers seem to be ideally suited for capturing short activity (i.e. Sampledat e.g. $30 \mathrm{H}$ ) which are beneficial to human health (Freedson et. al. 2005; Janz et. al. 2010). Statistical analysis of the collected data showed a statistically significant correlation between body mass index BMI, covered distance and energy expenditure expressed in $\mathrm{kcal}$ and also the number of steps that a participant made during its trial and the energy balance expressed in MET.

Table 3. Spearman rank order correlation

\begin{tabular}{|c|c|c|c|c|c|c|c|}
\hline \multirow{2}{*}{ Variable } & \multicolumn{7}{|c|}{ Spearman rank order correlations $p<0.05000$} \\
\hline & $\mathrm{BMI}$ & age & distance $[\mathrm{m}]$ & kcals & METs & axis 1 counts & step counts \\
\hline BMI & 1 & -0.338240 & -0.898650 & -0.231910 & -0.289890 & 0.463817 & 0.376851 \\
\hline Age & -0.338240 & 1 & 0.115954 & 0.289886 & 0.173931 & 0.086966 & -0.173930 \\
\hline Distance $[\mathrm{m}]$ & -0.898650 & 0.115954 & 1 & -0.142860 & -0.085710 & -0.657140 & 0.028571 \\
\hline kcals & -0.231910 & 0.289886 & -0.142860 & 1 & 0.892857 & 0.607143 & -0.821430 \\
\hline METs & -0.289890 & 0.173931 & -0.085710 & 0.892857 & 1 & 0.500000 & -0.750000 \\
\hline Step Counts & 0.376851 & -0.173930 & 0.028571 & -0.821430 & -0.750000 & -0.392860 & 1 \\
\hline
\end{tabular}

Source: the authors' research.

In Table 3 the analyzed seven parameters, for which the Spearman correlation test was done, are presented. This test showed a high correlation between six variables analyzed. To check whether results obtained in the study correlate the values of one variable are presented in order from the smallest to the largest and it has been checked whether the other parameters listed will work similarly.

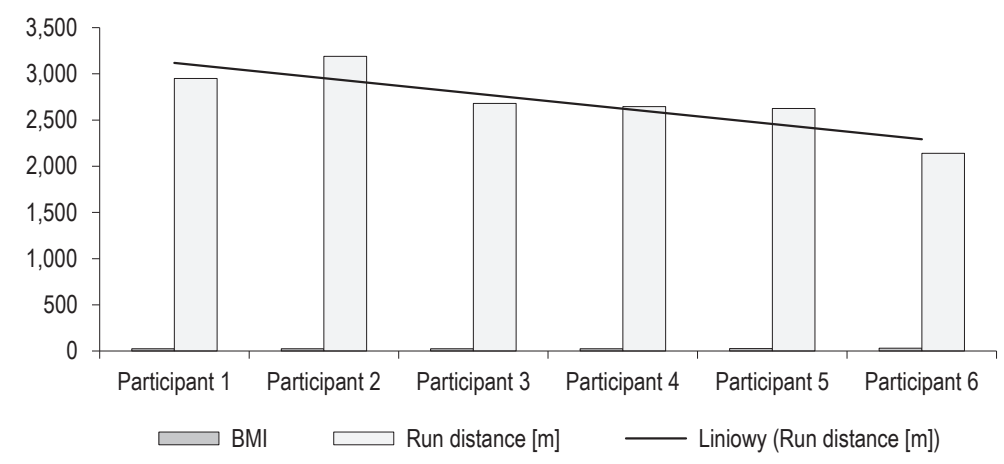

Figure 5 . Summary of body mass index from the smallest to the largest with run distance

Source: the authors' research.

$\mathrm{BMI}$ and the distance surveyed in order from lowest to highest BMI values were put together (Figure 5). It turned out that the higher value of body mass index BMI examined the shorter distance they covered during the trial. Spearman's rank order test showed that there was a strong correlation here, exhibiting statistical significance. 


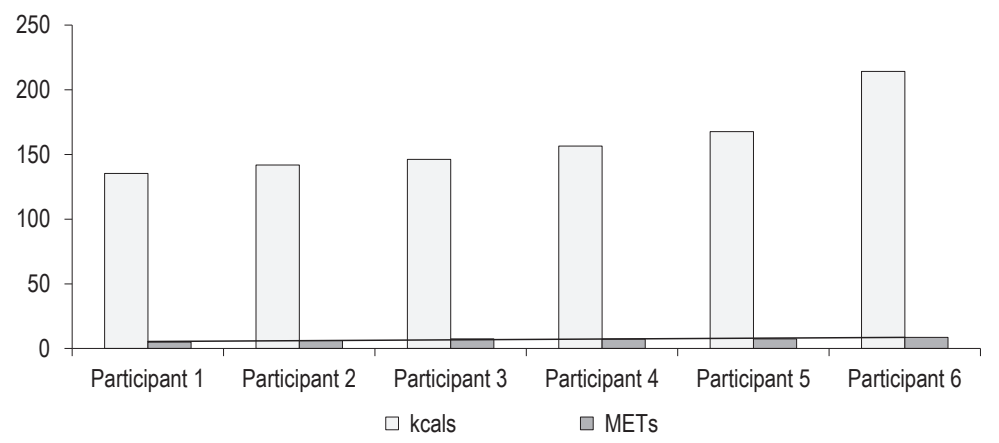

Figulp 6 . Summary of the energy balance expressed in MET from the smallest to the largest with the energy [kcals]

Source: the authors' research.

Analysis of survey results also showed a strong correlation between balance and energy expenditure of the respondents. Along with an increase in the first variable significantly increased the value of the other one. This relationship also proved to be statistically significant.

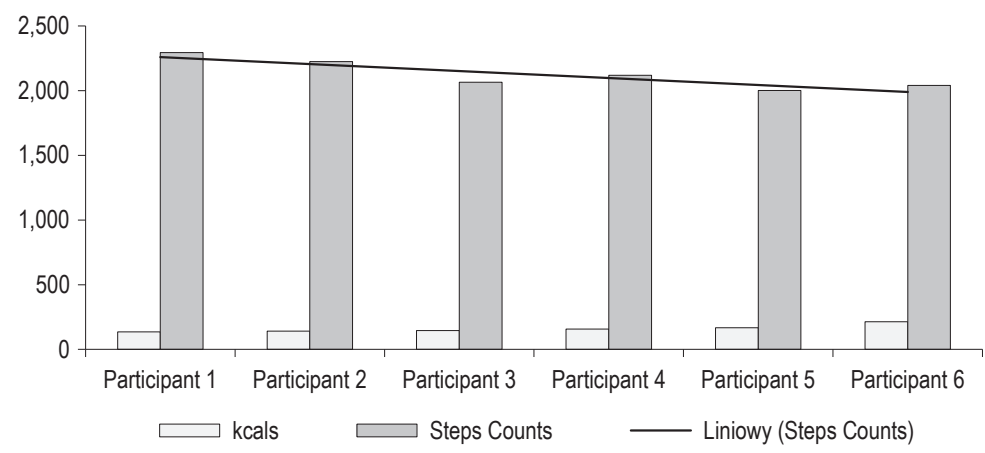

Figulp 7. Statement of energy expenditure expressed in kcals with the number of steps taken during Cooper test Source: the authors' research.

Based on the results of the analysis, it can also be concluded that there is a strong and statistically significant correlation between energy expenditure and the number of steps taken by the respondents during the 12 minutes run. It turned out that with the increase in energy expenditure the number of steps taken during the Cooper test decreased. This test in the most of articles is regarded as the basic test of the efficient use of aerobic energy sources (Cooper 1970; Raczek 1981; Sharkey 1990). According to the data presented in the tables, test results were very good and good. Furthermore, the interdependence between the Cooper test result (your distance) and $\mathrm{BMI}$ seems to be interesting. We can observe very good results at a high BMI from Cooper tables (BMI - 30.96 distance 2,950 meters). It is assumed that from 1,000 to 2,000 kcal should be consumed by physical exercise per week, what accounts for about 300 kcal per unit of training (Nowak and Nowak 2010; Rütten et. al. 2003). 
In the case of above studies in the 12-minute run, participants burned between 140 and $210 \mathrm{kcal}$ what gives the average of $175 \mathrm{kcal}$. In studies of Grzywocz and Skowronek (2012) a group of surveyed people during onehour-long training - jogging and fitness- burned an average of $478 \mathrm{kcal}$. The average was in this case less than 100 calories per 12 minutes. Additionally, according to the assumptions of Paffenbarger et al. (1990) for an adult of $70 \mathrm{~kg}$ the minimal energy expenditure is $2,000 \mathrm{kcal} \times w \mathrm{k}-1$ (approximately $300 \mathrm{kcal} \times$ day -1 ). Significant reduction in risk of myocardial infarction could be achieved with an effort of about 2,000 kcal per week. Physical activity related energy expenditure $>1,000 \mathrm{kcal} /$ week $(4,200 \mathrm{~kJ} /$ week) is associated with a $30 \%$ reduction in total mortality (for Zadarko et. al. 2011). It can therefore be assumed that the significant part of the assessment of the effectiveness of appropriately selected loads in health training is the heart rate and calories burned.

According to scientific findings (Biernat et. al. 2007) $1 \mathrm{MET}$ is $3.5 \mathrm{ml} \mathrm{O} / \mathrm{kg}$ of body weight per minute. It was determined that strenuous exercise requires 8 MET every minute of its duration, moderate effort requires 4 MET and walking (walking, fast walking) 3.3 MET. Calculating the total energy expenditure and thus, establishing participants' level of physical activity requires the multiplication of the frequency and the duration of exercise by its intensity expressed in MET units. In this study, the effort was between 4.5 and 8 MET (within 12 minutes of the test). In the study by Topolska et al. (2011) the average was 34.65 MET hours/week, while the research in eight countries of the European Union on physical activity were as follows: Belgium - 67.0 MET hours/week, Finland - 70.2 MET hours/week, France - 63.8 MET hours/week, Germany - 84.5 MET hours/week, Italy - 19.6 MET hours/week, Netherlands - 56.4 MET hours/week, Spain - 39.3 MET hours/week and UK - 27.6 - MET hours/week.

Schneider et al. (2004) compared 13 different models of pedometers in a 24-hour period. They found that some of them underestimate number of registered steps (error up to $25 \%$ ), while others greatly overestimate it (error up to $45 \%$ ). In this case, accelerometers equipped with piezoelectric motion sensors register every motion much more accurately than pedometers. The daily number of steps reaching over 10,000 is recommended for an active lifestyle, over 12,000 for better shape of body weight (Leermakers et. al. 2000), while it is recommended for children to take up to 12,000-16,500 steps per day (Bohannon 2007). In the case of this study it is the interval between 2,000 and 2,300 meters within 12 minutes.

The measurements of various vital signs, including human physical activity, with the use of portable devices is an increasingly common method for monitoring these signs in the world today (Lawrence et. al. 2005).

\section{Conclusions}

1. ActiGraph model WGT3X is a useful device for monitoring physical activity (measured number of steps and mets metabolic equivalent), as well as energy expenditure (kcal).

2. This analysis provided quantitative estimation of an activity of persons participating in the Cooper Test. The authors agree that it is necessary to further analyze different parameters.

3. This study showed a statistically significant correlation between energy expenditure and the number of steps made by respondents during the 12-minutes run.

\section{References}

Bassett D.R., Ainsworth B.E., Swartz A.M., Strath S.J., O'Brien W.L., King G.A. Validity of four motion sensors in measuring moderate intensity physical activity. Medicine \& Science in Sports \& Exercise. 2000; 32 (9): 471-480.

Bielski J. Życie jest ruchem. Kultura Fizyczna. 1996; 12-13, Warszawa. 
Biernat E., Stupnicki R., Gajewski A.K. Międzynarodowy Kwestionariusz Aktywności Fizycznej (IPAQ) - wersja polska. Wychowanie Fizyczne i Sport. 2007; 51 (1): 47-54.

Bohannon R.W. Number of pedometer-assessed steps taken per day by adults: a descriptive meta-analysis. Phys. Ther. 2007; (87) 12: 642-1650.

Cain K.L., Conway T.L., Adams M.A., Husak L.E., Sallis J.F. Comparison of older and newer generations of Act Graph accelerometers with the normal filter and the low frequency extension. IJBNPA. 2013: 10-51.

Cooper K.H. The new aerobics. In: Bantam. New York 1970.

Drabik J. Wytrzymałość i jej uwarunkowania somatyczne u dzieci i młodzieży w wieku 8-19 lat. AWF, Gdańsk 1989.

Drabik J. Promocja aktywności fizycznej. 1996: 3, AWF, Gdańsk.

Dwyer T., Hosmer D., Hosmer T., Venn A.J ., Blizzard C.L., Granger R.H., Cochrane J.A., Blair S.N., Shaw J.E., Zimmet P.Z., Dunstan $D$. The inverse relationship between number of steps per day and obesity in a population - based sample - the AusDiab study. Int. J. Obes. 2007; 31: 797-804.

Esliger D.W., Tremblay M.S. Establishing a profile of physical activity and inactivity: the next generation. Appl Physiol Nutr Metab. 2007; 32 (Suppl 2F): 217-300.

Freedson P.S., Pober D., Janz K.F. Calibration of accelerometer output for children. Medicine and Science in Sports and Exercise. 2005; 37: 523-530.

Grzywocz R., Skowronek T. Tętno wysiłkowe i wydatek energetyczny w ocenie efektywności treningu zdrowotnego kobiet uprawiających Nordic Walking. Jogging i Fitness. AWF, Wrocław. 2012; 38: 151-157.

Herbert J., Czarny W. Accelerometer wgt3x addition to studies of physical activity. Scientific Review of Physical Culture. 2013; (3) 3: 167-172.

Hussey J., Bell Ch., Gormley J. The measurement of physical activity in children. Phys Ther Rev. 2007; 12: 52-58.

Janz K.F., Lectuchy E.M., Eichenberger Gilmore J.M., Burns T.L., Torner J.C., Willing M.C., Levy S.M. Early physical activity provides sustained bone health benefits later in childhood. Medicine and Science in Sports and Exercise. 2010; 42: 1072-1078.

Lawrence D.F., Schmid T.L., Sallis J.F., Chapman J., Saelens B.E. Linking objectively measured physical activity with objectively measured physical form. Am. J. Prev. Med. 2005; 28: 117-125.

Leermakers E.A., Dunn A.L., Blair S.N. Exercise management of obesity. Med. Clin. North Am. 2000; 84: 419-440.

Malina R.M. Physical Activity in early and modern populations: an evolutionary view. In: Physical Activity in Early and Modern Populations/The American Academy of Physical Educations. The Academy Papers, Champaign. 1988; 21, Hum. Kin. Publ. 1-12.

Midorikawa T., Tanaka S., Kaneko K., Koizumi K., Ishikawa-Takata K., Futami J., Tabata I. Evaluation of low intensity physical activity by triaxialaccelerometer. Obesity (Silver Spring). 2007; (15) 12: 3031-3038.

Nowak Z., Nowak A. Znaczenie aktywności ruchowej w profilaktyce chorób sercowo-naczyniowych. Cz. II, Rehabilitacja w Praktyce. 2010; $1: 31-34$.

Osiński W. Antropomotoryka. AWF, Poznań, 2001.

Osiński W. Antropomotoryka. pub. II, AWF, Poznań, 2003: 320-330.

Paffenbarger R.S. Jr, Hyde R.T., Wing A.L. Physical activity and physical fitness as determinants of health and longevity. In: Exercise, fitness, and health, eds. C. Bouchard, R.J. Shephard, T.S. Stephens, J.R. Sutton, B.D. McPherson. Human Kinetics Publishers, Champaign, IL (USA). 1990; 33-48.

Raczek J. Rozwój wytrzymałości dzieci i młodzieży. Sport i Turystyka. 1981. Warszawa.

Rütten A., Ziemainz H., Schena F., Stahl T., Stiggelbout M., Auweele Y.V., Vuillemin A., Welshman J. Using different physical activity measurements in eight European countries. Results of the European Physical Activity Surveillance System (EUPASS) time series survey. Public Health Nutr. 2003; 6: 371-376.

Schneider P.L., Crouter S.E., Bassett D.R. Pedometer measures of free-living physical activity: Comparison of 13 models. Medicine and Science in Sports and Exercise. 2004; 36: 331-335

Sharkey B.J. Physiology of fitness. Human Kinetics.1990. Champaign.

Silcott N.A., Bassett D., Thompson D.L., Fitzhugh E.C., Steeves J.A. Evaluation of the omron HJ-720lTC pedometer under free-living conditions. Medicine \& Science in Sports \& Exercise. 2011; 43 (9): 1791-1797.

Topolska M., Sapuła R., Topolski A., Maciejewski M., Marczewski K. Aktywność fizyczna a zdrowie u kobiet w wieku od 19 do 65 lat w różnych dziedzinach życia. Zamojskie Studia i Materiały, Zamość, XIII, 2011, 1 (34). 
Troiano R.P., Freedson P.S. Promises and pitfalls of emerging measures of physical activity and the environment. Am J Prev Med. 2010; 38 (6): 682-683.

Vuori I. Physical inactivity as a disease risk and health benefits of increased physical activity. In: P. Oja, J. Borms. Perspectives. The Multidisciplinary Series of Physical Education and Sport Science: Health Enhancing Physical Activity. 2004: 29-73.

Zadarko E., Barabasz B., Nizioł E. Ocena poziomu aktywności fizycznej studentek wybranych kierunków medycznych na tle badań populacyjnych. PM UR i NILwW. 2011; 12: 188-194.

Cite this anticle aS. Herbert J., Matłosz P., Czarny W., Śliż M. An Objective Assessment of Men's Physical Activity during Cooper Test based on the Direct Monitoring by Accelerometer ActiGraphWGT3X. Central European Journal of Sport Sciences and Medicine. 2015; 12 (4): 99-108. 